\title{
Proximate Nutritional Evaluation of Maize and Rice - Gluten Free Cereal
}

\author{
Ridhi Kataria \\ Department of Foods and Nutrition CCS HAU, Hisar-125004
}

\begin{abstract}
Gluten is a protein found in cereals like wheat and other similar proteins found in rye and barley. These proteins damage the villi that line the small intestine, when damaged and inflamed, the villi are unable to absorb water and nutrients, this causes celiac patients susceptible to a variety of other conditions related to malabsorption. Therefore, a strict gluten free diet without cereals containing gluten proteins is essential. The present investigation entitled "Proximate nutritional evaluation of maize and rice - gluten free cereal" was carried out to utilize maize and rice for the development of gluten free food products. Keeping in view the need to develop gluten free food products to counter the associated nutritional needs of celiac disease patients, the present study was thus undertaken. Results of nutritional analysis of raw ingredients used for product development indicated ash-1.49\%, moisture- $6.8 \%$, crude protein- $8.9 \%$, crude fat- $4.47 \%$, crude fiber- $1.38 \%$ in maize And ash- $0.67 \%$, moisture- $11.8 \%$, crude protein- $7.2 \%$, crude fat- $0.9 \%$, and crude fiber- $0.5 \%$ in rice. Developed food products can satisfy palate of wheat allergy patients and fulfill their desire to consume these foods when made gluten free. There is a need to educate masses regarding preparation of gluten free foods.
\end{abstract}

Key words: Gluten, Maize, Rice, Development, Patients, Protein.

\section{Introduction}

In India, maize is grown in a wide range of environments, extending from semi-arid to sub- humid and humid regions. The crop is also very popular in the low and mid-hill areas of the western and northeastern regions. Rice starch is usually digested quite rapidly, compared with other starchy foods. Rice protein is valuable because it has unique hypoallergenic properties and ranks high in nutritive quality (rich in the essential amino acid lysine) among the cereal proteins. Apart from carbohydrate and protein, it provides reasonable amount of other nutrients viz., minerals and vitamins such as phosphorus, calcium, magnesium, potassium, iron, zinc, copper, manganese, thiamin, niacin and riboflavin. Moreover, it has only a trace of fat, sodium and gluten (Roy et al., 2008). Celiac disease is both a disease of malabsorption meaning nutrients are not absorbed properly $\&$ an abnormal immune reaction to gluten. When people with celiac disease eat foods or use products containing gluten, their immune system responds by damaging villi-the tiny finger-like protrusions lining the small intestine. Villi normally allow nutrients from food to be absorbed through the walls of small intestine into the blood stream. Without healthy villi, a person becomes malnourished; no matter how much food one eats (Fasano et al., 2003). For most people following this diet will stop symptoms and prevent further damage. The only treatment for celiac disease is a gluten free diet. Therefore, a strict gluten free diet without cereals containing gluten proteins (wheat, barley, rye, and triticale) is essential (Gallagher et al., 2004). Such a diet improves the health related quality of life in terms of less symptoms of the disease and normalized microvilli, which is of upmost importance for gastrointestinal functions. Supportive nutritional care in the case of iron, calcium, and vitamin deficiencies has also been recommended by (Hopman et al., 2006). Keeping in view the need to develop gluten free food products to counter the associated nutritional needs of celiac disease patients, the present study was thus undertaken with the following objectives.

\section{Objectives:}

To determine the proximate nutritional composition of maize and rice gluten free cereal.

\section{Literature Review}

The study was planned to utilize maize and rice cereals for the development of gluten free food products. Maize is a major cereal crop for both livestock feed and human nutrition. With its high content of carbohydrates, fats, proteins, some of the important vitamins and minerals, maize acquired a well-deserved reputation as a 'poor man's nutricereal'. ) Rice is known as queen among cereals due to its nutritional value and higher digestibility. It contains starch as principal component (80\%) and protein $(8 \%)$ as the second highest component (Marshall and Wordsworth, 1994) Maize crop has a special place in Indian agriculture and is staple food of people of Uttar Pradesh, Punjab, and Rajasthan especially for low socioeconomic group (Deosthale and Pant, 1971; Reddy et al., 1991). In India, over 90 per cent of the maize produced is used directly as food 
(Dhaliwal et al., 2002). In this chapter, the relevant literature pertaining to the objectives of the present investigation has been reviewed and presented under the following headings:

\subsection{Gluten free foods for celiac disease patients \\ 3.1 Gluten free foods for celiac disease patients}

Sverker et al., (2005) strongly supported the opinion that currently the only treatment of celiac disease is a strict gluten free diet for life. Patients can use maize, rice, oats, pulses and soya instead of wheat flour. There is clinical and histological improvement on a strict gluten free diet and relapse when dietary gluten is reintroduced (Farell and Kelly, 2006). Janeway et al (1999) reported that rice and corn have generally been considered as safe grains for celiac patients. When these were supplemented in the diet of celiac patients showed no harmful effects. Different protein sources can be added for improving the nutritional quality of gluten- free products, given that celiac disease in some cases leads to malnutrition. Soybean proteins were reported as the most used proteins in gluten-free bread formulations as pulses are gluten free in nature (Gallagher et al., 2002).

3.2 Proximate composition: - The information on proximate principles of maize and rice grain as reported by various researchers has been reviewed and given in under table:

Proximate composition (\%) of maize grains: -
\begin{tabular}{|l|l|l|l|l|l|}
\hline Crude protein & Crude fat & Ash & Crude fibre & Moisture & Reference \\
\hline $9-10$ & $4-5$ & $1-2$ & 3 & - & UNIDO (1986) \\
\hline $7.86-8.41$ & $1.15-1.21$ & $0.96-1.14$ & - & $11.15-11.29$ & Deka (1990) \\
\hline $8.89-13.53$ & $3.58-5.86$ & $1.68-2.97$ & $1.96-2.95$ & $6.00-7.50$ & $\begin{array}{l}\text { Khader \& Phani } \\
(1997)\end{array}$ \\
\hline 12.63 & 4.60 & 1.55 & 2.60 & - & Gupta (2001) \\
\hline $4.10-12.98$ & $3.98-5.45$ & $1.18-1.50$ & - & - & $\begin{array}{l}\text { Yadav \& Yadav } \\
(2002)\end{array}$ \\
\hline 8.96 & 4.09 & 1.33 & 1.48 & 7.15 & Edema (2005) \\
\hline 11.20 & 4.42 & 1.27 & 2.35 & 9.85 & $\begin{array}{l}\text { Aminogo \& ogutunde } \\
(2000)\end{array}$ \\
\hline
\end{tabular}

\subsection{Rice}

Goyal and Sharma (1998) estimated crude protein content of Indian rice varieties, the protein content was found in the range of 6.66 to 7.87 per cent. Deka (1998) analyzed the nutritional characteristics of rice varieties and reported that moisture content varied from 11.15 to 11.29 , proteins 7.86 to 8.41 , crude fiber 0.46 to 0.92 , fat 1.15 to 1.21 and ash 0.96 to 1.14 per cent. Cameron and Wang (2005) recorded the per cent composition of milled rice cultivars in the range of 6.6 to $9.3,0.18$ to 0.51 and 9.0 to 11.0 for crude protein, crude fat and moisture content, respectively. Vidal et al. (2007) estimated the protein and ash content in the range of 5.6 to 10.5 and 0.19 to 0.68 per cent in different varieties, respectively. Shabbir (2009) recorded moisture, fat, protein, fiber and ash in the range of 9.59 to $11.18,0.89$ to $1.17,6.38$ to $7.20,0.27$ to 0.41 and 0.59 to 0.67 per cent, respectively in four rice varieties. The mean values for moisture, crude protein, fat, crude fiber and ash of rice varieties were 11.50, 5.8, 2.5, 1.6 and 0.9 per cent, respectively (Oko and Onyekwere, 2010). Kim et al. (2004) estimated mineral content of milled rice varieties in the range of 6.0 to $9.4 \mathrm{mg} / 100 \mathrm{~g}$ for calcium. Singh (2005) reported that mineral content among rice varieties ranged from 11.21 to 13.47 for calcium, 2.24 to 3.87 for iron and 3.48 to $6.96 \mathrm{mg} / 100 \mathrm{~g}$ of zinc. According to Anjum et al. (2007) the iron and zinc content varied from 1.57 to 1.94 and 1.44 to $2.97 \mathrm{mg} / 100 \mathrm{~g}$ for four rice varieties. Hemalatha et al. (2007) reported that zinc and iron content in rice were 1.08 and $1.32 \mathrm{mg} / 100 \mathrm{~g}$, respectively. Shabbir et al. (2008) observed that zinc and iron content in different rice varieties ranged from 1.31 to 1.41 and 0.77 to $0.91 \mathrm{mg} / 100$ $\mathrm{g}$, respectively. Liang et al. (2009) reported that white rice contained 173.0, 28.7 and $24.5 \mathrm{mg} / \mathrm{kg}$ calcium, iron and zinc, respectively.

\section{Material And Methodology}

The present investigation entitled "Proximate Nutritional Evaluations of Maize and rice - Gluten Free Cereal" was conducted in the Department of Foods and Nutrition, I.C College of Home Science, CCS Haryana Agricultural University, and Hisar.

4.1Proximate composition of maize grain: -

4.1.1 Moisture: - Moisture in the samples was calculated by employing the standard methods of analysis (AOAC, 2000).

Procedure: Five gram sample was weighed in a petri dish and dried in an oven at $60{ }^{\circ} \mathrm{C}$ temperature for six hours or till a constant weight was obtained. The sample was weighed. After cooling in a desiccator. 


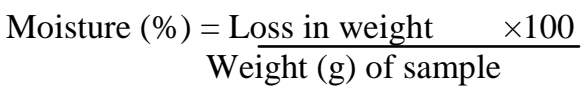

\subsubsection{Crude Protein}

Crude Protein was estimated using micro-kjeldahl method with KELPLUS nitrogen estimation system.

\section{Reagents}

i) Digestion mixture. $\mathrm{CuSo} 4$ and $\mathrm{K} 2 \mathrm{So} 4$ was mixed in ratio 1:8

ii) $\mathrm{H} 2 \mathrm{SO} 4$ : conc. $\mathrm{H} 2 \mathrm{SO} 4$

iii) $0.1 \mathrm{~N} \mathrm{HCl}$

iv) $4 \%$ Boric acid solution

v) $40 \% \mathrm{NaOH}$ solution

\section{Procedure}

Ten $\mathrm{ml}$ concentrated $\mathrm{H} 2 \mathrm{SO} 4,0.2 \mathrm{~g}$ sample and three g digestion mixture was taken in digestion tubes. Digestion system was switched on and the initial temperature of $100^{\circ} \mathrm{C}$ was set by pressing the temperature controller keys. The temperature controller was reset to $420^{\circ} \mathrm{C}$. Mixture was heated till digested and proper water flow was regulated to ensure absolute removal of acid fumes. After digestion contents were cooled and distillated in classic-DX (VA). Distillation unit was switched on and green indication was ensured. The hose was connected to the steam release outlet and let it to the drain. Boric acid and alkali were filled in the bottles in required quantity. Sample to be digested was loaded and door was closed before switching on the power in control panel. System was ready for operation after receiving ready indication and the programme was selected by pressing 'run' key. Addition of boric acid and alkali was done. The distillate was then titrated with N/10 hydrochloric acid to determine the ammonia absorbed in boric acid.

Crude Protein $(\%)=\frac{14.01 \times(\mathrm{S}-\mathrm{B}) \times \mathrm{N} \times 100}{\mathrm{~W} \times 1000}$

$$
\mathrm{W} \times 1000
$$

Conversion factor of 6.25 was used to calculate percent Protein.

Crude protein $\%=$ Nitrogen $(\%) \times 6.25$

Where, $\mathrm{W}=$ Weight of sample taken $(\mathrm{g})$

$\mathrm{N}=$ Normality of acid used for titration $(0.1 \mathrm{~N} \mathrm{HCl})$

$\mathrm{S}=$ Volume of standard acid $(0.1 \mathrm{~N} \mathrm{HCl})$ used for titration $(\mathrm{ml})$

$\mathrm{B}=$ Volume of $0.1 \mathrm{~N} \mathrm{HCl}$ used for blank $(\mathrm{ml})$

\subsubsection{Crude Fiber}

Crude fiber was estimated by the standard method of analysis (AOAC, 2000).

\section{Reagents}

i) Sulphuric acid stock solution $(\mathbf{1 0 \%}, \mathbf{w} / \mathbf{v})$ : Fifty five $\mathrm{ml}$ concentrated sulphuric acid was measured and volume made to 1 litre.

ii) Sulphuric acid working solution (1.25\%): Sulphuric acid stock solution was diluted to one litre.

iii) Sodium hydroxide stock solution $(\mathbf{1 0 \%}, \mathbf{w} / \mathbf{v})$ : One hundred twenty five gram sodium hydroxide was dissolved in water and diluted to one litre.

iv) Sodium hydroxide working solution (1:25\%): One hundred twenty five $\mathrm{ml}$ sodium hydroxide stock solution was diluted to one litre.

v) Alcohol

vi) Acetone

vii) Antifoam: 2\% silicon antifoam in CCl4

\section{Procedure}

One $\mathrm{g}$ of fat free dried sample was weighed and put in one litre tall beaker; $200 \mathrm{ml}$ of $1.25 \% \mathrm{H} 2 \mathrm{SO} 4$ was added. The solution was kept boiling for 30 minutes under bulb condensors. Beaker was rotated occasionally to mix the content and removed the particles from the sides. Content of the beaker was filtered 
through funnel. Sample was washed back into tall beaker with $200 \mathrm{ml}, 1.25$ per cent sodium hydroxide, brought to boiling point and boiled exactly for 30 minutes. All insoluble matter was transferred to the sintered crucible by means of boiling water until it became acid free, washed twice with alcohol, three times with acetone, dried at $100^{\circ} \mathrm{C}$ to constant weight, reweighed and ashed in a muffle furnace at $550^{\circ} \mathrm{C}$ for $1 \mathrm{~h}$. Crucible was cooled in a desiccator, reweighed and percentage of crude Fiber in the samples was calculated by using the formula:

Crude Fiber $(\%)=$ W $2-$ W $3 \quad \times 100$

Where,

$\mathrm{W} 1=$ Weight $(\mathrm{g})$ of sample

$\mathrm{W} 2=$ Weight $(\mathrm{g})$ of insoluble matter (weight of crucible + insoluble matter- weight of crucible)

$\mathrm{W} 3=$ Weight $(\mathrm{g})$ of Ash (crucible + Ash - wt. of crucible)

\subsubsection{Fat}

Crude fat was estimated by standard method (AOAC, 2000) using soxhlet extraction apparatus.

\section{Procedure}

A weighed amount $(2 \mathrm{~g})$ of dried sample was transferred to an extraction thimble dried overnight at $60^{\circ} \mathrm{C}$ temperature. The thimble was placed in a soxhlet extractor fitted with a condensor and flask containing sufficient petroleum ether $\left(\mathrm{BP} 60-80^{\circ} \mathrm{C}\right)$. After $6 \mathrm{~h}$ extraction, thimble was removed from the extraction apparatus and dried in the hot air oven to a constant weight, cooled in a desiccator to room temperature and weighed. Loss of weight of thimble indicated the amount of fat in the sample.

$$
\text { Fat }(\%)=\frac{\text { loss of weight } \quad \times 100}{\text { Sample weight }}
$$

\subsubsection{Ash}

Ash in the sample was estimated by employing the standard method of analysis (AOAC, 2000).

\section{Procedure}

Five gram of dried sample was taken in a weighed crucible and ignited until no charred particles remained in the crucible and then the crucible was put in muffle furnace $\left(550^{\circ} \mathrm{C}\right)$ for $6 \mathrm{~h}$ or until a white Ash was obtained. Thereafter, the crucible was cooled in a desiccator and reweighed.

$$
\text { Ash }(\%)=\frac{\text { Weight }(\mathrm{g}) \text { of Ash } \quad \times 100}{\text { Weight }(\mathrm{g}) \text { of sample }}
$$

Wt. of crucible $=\mathrm{W} 1$

Wt. of crucible + Ash $=\mathrm{W} 2$

Weight $(\mathrm{g})$ of Ash $=$ Wt. of crucible + Ash - wt. of crucible= W2- W1

\section{Results}

In the present study, efforts were made to utilize maize and rice for development of gluten free food products for celiac disease patients. The maize and rice tested according to the standard methods of estimation AOAC 2000. The results of nutritional composition of maize and rice are show in table [1].

5.1 Proximates Nutritional Evaluation Of Maize And Rice (Table 1)

\begin{tabular}{|l|l|l|l|}
\hline SR. NO. & PROXIMATES & AMOUNT (Rice) & AMOUNT (Maize) \\
\hline 1. & MOISTURE CONTENT & $11.8 \%$ & $6.8 \%$ \\
\hline 2. & ASH CONTENT & $0.67 \%$ & $1.49 \%$ \\
\hline 3. & CRUDE FIBRE & $0.5 \%$ & $1.38 \%$ \\
\hline 4. & CRUDE PROTEIN & $7.2 \%$ & $8.9 \%$ \\
\hline 5. & CRUDE FAT & $0.9 \%$ & $4.47 \%$ \\
\hline
\end{tabular}




\section{Conclusion}

Maize tested according to the standard methods of estimation AOAC 2000. Maize contained about 6.8 percent moisture. Protein content in maize was 8.9 percent, Ash content was found to be 1.49 percent. The crude fiber was 1.38 percent, crude protein was 8.9 percent and crude fat was 4.47 percent (table 1). The maize cereal was evaluated for nutritional proximate principles for celiac disease. They provide nutritionist food for the persons who is suffered from celiac disease. Developed food products can satisfy palate of wheat allergy patients and fulfill their desire to consume these foods when made gluten free. Moreover, celiac disease is often accompanied with other nutritional deficiencies, and gluten free cereal maize in the present study, will provide such nutrients that problem of nutritional deficiencies could be dealt easily and effectively. Gluten free cereal maize has better nutritional profile, so these cereals can serve as a potential alternative for expensive gluten free available commercially. There is a need to educate masses regarding preparation of gluten free foods; so that these can be easily prepared at home and small enterprise for gluten free products can be established.

\section{Acknowledgement}

If there is God on Earth it is you. "Dedicated to my revered and beloved Father"

With the grace of Almighty I am able to carve another milestone in my academic journey. Like a light house that signals the ship to the shore, is my guide, a good ray of hope, she led to better knowledge and understanding all through my search for wisdom. I allide this present opportunity to express my deep sense of gratitude and obligation to my esteemed Major Advisor, Dr. (Mrs.) Asha Kawatra, Professor, Department of Foods and Nutrition for her able and sustaining guidance, continuous encouragement, constructive and valuable suggestions throughout the course of this investigation. It is my pleasure to express my thanks to the teaching and non-teaching staff members who encouraged me from time to time and helped me whenever I needed.

Words can never express my gratitude to my family members whose endless love, affection and untiring support and everlasting blessings bring me here. I express my heartfelt gratitude to my father Sh. Satbir Singh Kataria for providing valuable suggestions and motivation and my mother Mrs. Sumitra Kataria for her moral support who are like incarnation of God on this earth and who struggled throughout to provide me the best of everything in life. I bow my head to my parents for making me what I am and for bringing me where I am. Affectionate and rejuvenating support received from my brother Deepak Kataria is deeply cherished. Friendship needs no studied phrases, polished face or winking wiles.

I feel bereft of words in expressing my heartfelt gratitude to Mr. Kuldeep Jangra whose faith, patience and understanding enabled me to make this endeavour see the light of the day. He has been an indefinite source of inspiration and pillar of strength during completion of this study. They are my friends Mahima, Vatsala, Priyanka, Sonia, Monika and Poonam who at times criticized, scolded and encouraged me to keep my determinacy to reach at proper decision. Last but not the least, I am thankful to all those who helped me directly or indirectly during my course of study.

\section{Reference}

[1]. Aminogo, E.R. and Ogutunde, A.O. 2000. Functional properties and nutritive composition of maize (Zea mays) as affected by heat treatments. J. Food Sci. Technol. 37 (1): $11-15$.

[2]. AOAC. 2000. Official Methods of Analysis. Association of Official. Analytical Chemists, Washington, D.C. USA.

[3]. Babu, R., 2005. Quality Protein Maize in North Western India: Full of protein and potential. India council for Agricultural Research (ICAR), 3: 45-52.

[4]. Deka, R.K. and Sarkar, C.R. 1990. Nutrient composition and anti-nutritional factors of Doli chos lablab L. seeds. Fd. Chem. 38 : 239- 246.

[5]. Deosthale, Y.G. and Pant, K.C. (1971). Nutrient composition and amino acid pattern of some high yielding maize varieties. The Ind. J. Nutr. Dietet. 8: 244- 248.

[6]. Dhaliwal, Y.S., Dogra, J. and Awasthi, C.P. (2002). Approaches in maize processing and potentials of its industrial utilization. In: Adv. Maize Prodn. Tech. and Quality Impvt. Proc. Proceedings of National Seminar on Science- Industry Interface on Maize Production, Processing and Utilization, HPKV, Palampur, Nov 3-4, 2000. pp: 115-122.

[7]. Edema, Mojisola O.; Sanni, Lateef O. and Sanni, Abiodun I. 2005. Evaluation of maize- soyabean flour blends for sour maize bread production in Nigeria. African J Biotechnol. 4(9): 911-918.

[8]. Farrell RJ, Kelly CP. 2002. Celiac sprue. N Engl J Med 346(3): 180-188.

[9]. Fasano, A., Berti, I., and Gerarduzzi, T. 2003. Prevalence of celiac disease in at-risk and not-at-risk groups in the United States: A large multicenter study. Arch. Intern. Med. 163:286.292.

[10]. Gallagher, E., Gormley, T. R., and Arendt, E. K. 2004. Recent Advances in the formulation of gluten free cereal-based products and trends. Food Science and Technology.15: 143-152.

[11]. Gupta, V. 2001. Nutritional and sensory evaluation of value added bakery products. M.sc. Thesis. CCSHAU, Hisar, India.

[12]. Hopman, E.G., Le, Cessie S., Blomberg, B.M. and Mearin, M.L. 2006. Nutritional management of the gluten-free diet in young people with CD in the Netherlands. J Pediatr Gastroenterol Nutr. 43:102.108.

[13]. Janeway, C. A., Travers, P., and Walport, M. 1999. The Immune System in Health and Disease . J. of Immunobiology:, 4: 142145.

[14]. Khader, V. and Phani, V.1997. Nutritive value and in vitro digestibility characteristics of maize (Zea mays L.) Indian Food Packer. March- April: 30- 35.

[15]. Marsh MN. Gluten major histocompatibility complex and the small intestine. A molecular and immunobiologic approach to the spectrum of gluten sensitivity (.celiac sprue.). Gastroenterology. 1992; 102:330.54. 
[16]. Marshall, W.G. and Wordsworth, J.I. 1994. Rice Science and Technology., New York: Marcel Dekker, Inc. 237-259

[17]. Reddy, N.S., Kamble, R.M. and Khan, T.N.I. (1991). Evaluation of nutritional quality of maize and maize products. The Ind. J. Nutr. Dietet. 28: 90-94.

[18]. Roy, P., Ijiri, T., Okadome, H., Nei, D., Orikasa, T., Nakamura, N. and Shiina, T. 2008. Effect of processing conditions on overall energy consumption and quality of rice. J. Food Eng. 89: 343 348. doi: 10, 1016/j.jfoodeng.2008.05.015.

[19]. Showemimo, F.A., J.E. Onyibe, S.R. Ajibade, A. Danbaba, and A. Adepoju, 2005. Potentials of Quality Protein Maize production and promotion in Nigeria. Paper presented at the Sasakawa Global 2000. Training workshop on Quality Protein Maize (QPM) Development and seed Delivery system, Kumasi, Ghana $4-15$ August 2005.

[20]. Sverker, A., Hensing, G.and Hallert, C. (2005) .Controlled By food.Lived experiences of celiac disease. Journal of Human Nutrition \& Dietetics 1:171-10. UNIDO. 1986. Technical Memorandum.

[21]. Yadav, S.S. and Yadav, R.P. 2002. Studies on some quality traits of maize (Zea mays L.) genotypes. In: Adv. Maize Prodn. Tech. and Quality Impvt. Proc. Proceedings of National Seminar on Science- Industry Interface on Maize Production, Processing and Utilization, HPKV, Palampur, Nov 3-4, 2000. Pp: 181- 183. 